tablished by Dr. Daniel J. Boorstin, Librarian of Congress, to review the LC operation with an eye toward reorganization.

She was a recipient of the John S. Brubacher Award from the Center for the Study of Higher Education at the University of Michigan in 1975 for her outstanding graduate essay on the history and philosophy of higher education.

Her publications included: Aspects of the Junior College Field, A Bibliography, AACJC, 1969; "Planning Community College Resource Centers," American Libraries, January 1971; "Focus on Community College Libraries," Michigan Librarian, Summer 1971; “The Black Librarian as Change Agent" in What Black $\mathrm{Li}$ brarians Are Saying, edited by E. J. Josey, Scarecrow Press, 1972; "On the Cutting Edge of Change" in New Dimensions in Academic Library Service, edited by E. J. Josey, Scarecrow Press, 1973.

Edwin C. Giles attended Kent State University. He was graduated from Wayne State University, Detroit, Michigan, with a master of arts degree in administration. He taught in the school system of Detroit and for the past few years he was principal of the Scripps Elementary School.

Mr. and Mrs. Giles are survived by their daughter, Susan, 19, who is a student at City University of New York; her mother, Mrs. Roberta Glenn; her sister, Mrs. Elsie Ashworth; and his mother, Mrs. Doll Giles, all of Akron, Ohio. Memorial contributions may be made to the Detroit Chapter of the NAACP, 2990 E. Grand Blvd., Detroit, MI 48202; Big Brothers of Detroit, 15800 W. McNichols, Detroit, MI 48235; or the Minority Scholarship Fund, ALA, 50 E. Huron St., Chicago, IL 60611.

\section{ALA MINORITY SCHOLARSHIP RENAMED FOR LOUISE GILES}

The following resolution was unanimously endorsed by the Board of Directors of the Association of College and Research Libraries and the ALA Awards Committee. It was approved by the ALA Council on February 1, 1977.

WHEREAS Louise Giles had served extensively and in a most dedicated manner the profession of librarianship, the American Library Association, and the academic and educational fields as: a leader among the ACRL Community and Junior College Libraries Section, serving in a number of offices, including that of Chairman; a leader in the Association of College and Research Libraries, serving as its President in 1975/76; and a leader in the cooperative and advisory programs between the American Library Association and the American Association of Com- munity and Junior Colleges; and

WHEREAS her untimely death has been a tragic loss and will continue to deprive the library world of her valuable assistance;

THEREFORE BE IT RESOLVED that the Council of the American Library Association recognize her loss by a moment of silence; and

BE IT FURTHER RESOLVED that she be remembered by naming the ALA Scholarship Program-Minority Scholarship as the Louise Giles Minority Scholarship; and

BE IT FURTHER RESOLVED that ALA members and other friends be invited to contribute to this fund.

\section{Fulbright-Hays Scholars}

The Fulbright-Hays scholars in library science for 1976-77 are:

GEORGE BoBINSKI-dean and professor, information and library studies, State University of New York, Buffalo. Library science, University of Warsaw, Poland, March-June 1977. Lecturing.

Allan D. Prate-assistant professor of library science, Indiana University, Bloomington. Library automation and information science, Danish Library School, Denmark, September 1976-June 1977. Lecturing.

News items for inclusion in C\&RL News should be sent to John $Y$. Crowley Assistant Director of Libraries, Milne Library, State University College, Oneonta, NY 13820. Advertising (including classified ads) should be sent to Leona Swiech, Advertising Office, American Library Association, 50 E. Huron St., Chicago, IL 6061I. Production and circulation matters are handled by ALA Central Production Unit, at the above address.

News editor: John V. Crowley, Assistant Director of Libraries, Milne Library, State University College, Oneonta, NY 13820 . Editor: Richard D. Johnson. Milne Library, State University College, Oneonta, New York 13820. President, ACRL:

Connie R. Dunlap. Executive Secretary, ACRL: to be announced.

College Research Libraries is published by the Association of College and Research Libraries, a division of the American Library Association, 17 times yearly-6 bimonthly journal issues and II monthly (combining July-August) News issues-at 1201.05 Bluff St., Fulton, MO 65251. Subscription, $\$ 15.00$ a year, or to members of the division \$7.50, included in dues. Second-class postage paid at Fulton, Missouri 65251 .

(C) American Library Association 1977. All material in this journal subject to copyright by the American Library Association may be photocopied for the noncommercial purpose of scientific or educational advancement. 